\title{
WALLS OF NIGERIA
}

\section{Family ties.}

\section{BY JEREMY SZAL}

$\mathrm{I}$ stare at the twisted remains of Lagos through the visor of my exosuit as I stalk down the hill. Buildings crumble and slide into the sea. Coils of fiery smoke curl up to the sky. So much work, so much craftsmanship. Gone in weeks.

I'm panting as I continue down the hill - with the cooling system broken, I'm swimming in sweat inside this thing. It's gunmetal grey, covering me from sole to scalp and weighing several hundred kilos. If it weren't for the hydraulics built along my spine, moving in it would be impossible. I have to make extra effort to control it now; the suit seems to have a mind of its own. Cancelling my HUD commands, seizing up at random intervals, cutting off my sensory details.

I'm nearing the school I used to attend, years before any of this happened. A few lone palm trees remain, fronds swaying in the sour wind. I remember being in class one stifling Tuesday, me and Tendai trying to sneak out when we first heard we'd captured one of the K'Dasewh. After all these years, we'd finally got an alien.

There are remains of a solider over by the school. An art mural covers the wall, unfinished words scrawled on blasted brick the colour of red earth. Chalk lies strewn on the ground. Even though his armour has been cracked open, it still pulses with blue bioluminescence. The suit had grown into his flesh like a graft, the metal and matte and wires worming through his dark skin like tendrils. I step over empty coconut shells to check his suit's reading to see when he died. Almost three months ago. Hed been wearing his suit for only two months and he's this far gone.

I've been inside mine for two years.

My skin crawls with the memory of being locked into our suits of armour, laced with alien DNA. They'd dissected these aliens, taken the self-healing and enhanced strength in their biotech and transferred it

$\rightarrow$ NATURE.COM

Follow Futures:

@ @NatureFutures

f go.nature.com $/ \mathrm{mtoodm}$ to us. For a while, it worked.

We didn't know that for the biotech to function and repair us, it needs living tissue. You can't get biomass from nothing. So the suit slowly grew inwards into flesh, tunnelling through open wounds and organs damaged from battle. Fusing into the wearer. The quarantine came around too late.

I wonder if I have any flesh left, if the cables have wrapped around my bones like creepers around a tree. If it's started corroding my brain, trying to take complete control of the suit. Tightening its grip by the day. But I have no way of knowing. And that scares me the most.

Over in the distance, there's a biosphere laid out over the ground - where some of the last human settlements still reside. We're not allowed within five klicks of them for risk of infection. They're still getting refugees from Ghana and Cameroon, but most of them have already been placed on offworld colonies and habitable planets outside the Solar System.

My wife and sons are among them. Ben should be six years old now and Emeka eight, maybe nine.

These are just the last few that have lingered behind on Earth to make sure that no one gets left behind. No one except us.

I log into my commander's channel. It takes me three tries to get it right; the suit attempts to cancel it. But I manage it.

"You still out there, son?" The grizzled face of Commander Somadina pops into my bottom-right vision. "I thought you were dead."

I wish I was. I truly do. "I'm still here."

"I wish I could help. But we can't let any of you Stained inside the sphere. We can't let the biotech virus spread, especially not to the new colony."

My jaws lock and my muscles tighten against my armour. "After everything we did?" I spread my arms, armour plates like fetters around my wrists. "We fought for this city with everything we had."

"And look what happened anyway." He shakes his head. "They sent their entire fleet and destroyed it."

No matter what we did - how hard we fought - it wasn't enough. By the time we'd destroyed the last of their ships, our world was broken.

I crane my neck to look at the sky. Somewhere, out in the giant cosmos of space, is my family. "At least let me talk to my wife one last time. Let me send a message."

"Cannot be done. We can't tell you where the colony is. What if they capture and torture you? Besides, your armour will store the location. All other Stained are in the same position."

I want to scream. I want to laugh like a madman. My throat's filled with concrete and every word feels like it's being fishhooked from my gut. Maybe now the suit has started consuming my throat and vocal cords. Soon I won't be able to speak. "So that's it?"

"I'm so sorry." He can't even look at me. "Goodbye, Kohban."

He cuts the connection. Leaving me here, shackles worming deeper and deeper into mybody.

The weight of my armour and of the cosmos pressing down on my shoulders, I stagger to the wall and scoop up some chalk. Hands shaking, I scrawl a message to my friends and family, to the people of Nigeria. I do it quickly, before the armour locks up. Telling them that I miss them - that I'm part of this world now. That the K'Dasewh will never have our planet.

And one day, when my people return to a new, clean Earth, this message will greet them. I hope I'm not here when that happens.

My eyes blur. It could be tears, or could be the suit trying to obscure my vision. I don't think I'll ever know for sure.

Jeremy Szal's work has appeared in Nature, Abyss \& Apex, Lightspeed and others. He lives in Sydney, Australia, and seeks literary representation. Find him at jeremyszal.com or@jeremyszal 